\author{
KatARZYNa CZERWińSKA-KoraL ${ }^{1}$
}

\title{
Possessio nuda, czyli czy istnieje jeszcze funkcja prawno-korygująca posiadania nieruchomości rolnych?
}

\section{Wstęp}

Posiadanie w stosunkach rolnych odgrywało i nadal odgrywa istotną rolę. Różne są funkcje posiadania. W literaturze mowa o funkcjach jurydycznej, ekonomicznej i społecznej posiadania ${ }^{2}$. Z punktu widzenia jurydycznego wyróżnia się trzy funkcje: zastępczą dla prawa własności, konstrukcyjno-prawną i wzbogacającą treść prawa ${ }^{3}$. Istnieje także podział na funkcję prawo-tworzącą, prawo-manifestującą i prawno-korygującą ${ }^{4}$. A. Stelmachowski zwracał uwagę na posiadanie jako uzewnętrznienie własności oraz posiadanie jako korekturę własności ${ }^{5}$ i w związku z tym w ustawodawstwie rolnym wyróżnił dwie tendencje: 1) dążność do uporządkowania stanu własnościowego przez dostosowanie stanu własności do posiadania, 2) oderwanie się od stanu własności i oparcie się wyłącznie na stanie posiadania 6 .

Mając na uwadze zmianę przepisów w zakresie zasiedzenia nieruchomości rolnych $^{7}$, celowe jest zwrócenie uwagi na realizację wskazanych nurtów ustawodawczych współcześnie. Pojawia się pytanie, czy ustawodawca nadal dąży do uporządkowania stanu własnościowego przez dostosowanie stanu własności, co zapewnia instytucja zasiedzenia oraz czy poprzez zmianę przepisów z zakresie zasiedzenia nie nastąpiło de facto wypaczenie prawno-korygującej funkcji posiadania?

Uniwersytet Śląski.

S. Kołodziejski, Jurydyczna funkcja posiadania, „Palestra” 1967, nr 5, s. 15; tenże, Ekonomiczna i społeczna funkcja posiadania, „Palestra” 1966, nr 6, s. 19.

A. Kunicki, (w:) System prawa cywilnego, praca zbiorowa, t. II, Wrocław 1985.

E. Gniewek, Prawo rzeczowe, Warszawa 2002, s. 273.

D. Łobos-Kotowska, Współczesne funkcje posiadania gruntów rolnych na gruncie przepisów statuujących pomoc unijną, (w:) Rozprawy z prawa prywatnego. Księga pamiątkowa dedykowana Profesorowi Aleksandrowi Oleszce, (red.) A. Dańko-Roesler, J. Jacyszyn, M. Pazdan, W. Popiołek, Warszawa 2012, s. 288.

6 A. Stelmachowski, Istota i funkcja posiadania, Warszawa 1958, s. 94-95, s. 117.

$7 \quad$ Wprowadzone przepisami ustawy z dnia 14 kwietnia 2016 r. o wstrzymaniu sprzedaży nieruchomości Zasobu Własności Rolnej Skarbu Państwa oraz o zmianie niektórych ustaw (Dz.U. z 2016 r., poz. 585 ze zm.). 


\section{Zasiedzenie jako realizacja korygująco-prawnej funkcji posiadania}

Posiadanie realizuje cel uporządkowania stosunków własnościowych. Chodzi tu przede wszystkim o sytuację, gdy z okoliczności sprawowania faktycznej władzy nad rzeczą może wyniknąć nabycie prawa własności. Dotyczy to w szczególności nabycia własności przez zasiedzenie ${ }^{8}$. Zasiedzenie jest instytucją prawną o wielowiekowej tradycji ${ }^{9}$. Jej podstawową funkcją jest nadanie, w interesie porządku prawnego, charakteru prawa zadawnionym stanom faktycznym, wytworzonym przez pozbawione tytułu prawnego długoletnie posiadanie cudzej rzeczy i przekształcenie posiadaczy we właścicieli ${ }^{10}$. Celem instytucji zasiedzenia jest zatem usunięcie rozbieżności między stanem prawnym a faktycznym, długotrwałym stanem posiadania $^{11}$. Z tych względów mówimy, że zasiedzenie jest objawem prawno-korygującej funkcji posiadania ${ }^{12}$, że jest korekturą własności ${ }^{13}$. Uzasadnieniem instytucji zasiedzenia jest również zapobieżenie narastającym w miarę upływu czasu trudnościom w dowodzeniu i ustaleniu podmiotu prawa własności, który jest uprawniony do rozporządzania rzeczą, a zarazem odpowiedzialny za tę rzecz ${ }^{14}$.

Legalizacja długo istniejących stanów faktycznych leży nie tylko w interesie posiadacza, ale także w interesie ogólnym. Przemawiają za nią względy gospodar$\mathrm{cze}^{15}$. Gdyby nie instytucja zasiedzenia, posiadacz nie byłby, choć jego posiadanie istniało przez długi czas, nigdy pewny czy tego posiadania nie zostanie pozbawiony, a to podważałoby bezpieczeństwo prawne ${ }^{16}$. Z tych przyczyn zasiedzenie należy uznać za instytucję porządkującą i stabilizującą stan prawny rzeczy ${ }^{17}$.

Ogólnie mówiąc, zasiedzenie jest pierwotnym sposobem nabycia własności rzeczy lub prawa przez nieuprawnionego posiadacza wskutek faktycznego wykonywania tego prawa przez określony ustawą czas, w którym właściciel mógł dochodzić

Posiadanie było także podstawą nabycia własności, przykładowo w dekrecie z dnia 6 września 1951 r. o ochronie i uregulowaniu własności osadniczych gospodarstw chłopskich na obszarze Ziem Odzyskanych oraz w ustawie z dnia 26 października 1971 r. o uregulowaniu własności gospodarstw rolnych. Należy wskazać, że posiadanie służy do nabycia nie tylko prawa własności, ale także służebności gruntowej, może być również podstawą roszczenia o wykup gruntu zgodnie $z$ art. $231 \mathrm{kc}$.

$9 \quad$ Zob. A. Stelmachowski, Istota i funkcja posiadania, op. cit., s. 100-115.

10 A. Stelmachowski, (w:) System Prawa Prywatnego. Prawo rzeczowe, Tom 3, T. Dybowski (red.), Warszawa 2007, s. 392; S. Rudnicki, (w:) G. Bieniek, S. Rudnicki, Nieruchomości. Problematyka prawna, Warszawa 2009, s. 1150; E. Skowrońska-Bocian, (w:) Kodeks cywilny. Tom I. Komentarz do artykułów 1-44911, K. Pietrzykowski (red.), Warszawa 2008, s. 618.

11 J. Naczyńska, (w:) Kodeks cywilny. Komentarz, t. II. Własność i inne prawa rzeczowe (art. 126-352), M. Habdas,

M. Fras (red.), Warszawa 2018, s. 238.

E. Gniewek, Prawo rzeczowe, op. cit., s. 90-91.

A. Stelmachowski, Istota i funkcja posiadania, op. cit., s. 96-97.

J. Naczyńska, (w:) Kodeks cywilny. Komentarz, op. cit., s. 238.

Zob. postanowienie TK z dnia 15 grudnia 1999 r., Ts 111/00, OTK 2000, nr 1, poz. 23.

E. Janeczko, Zasiedzenie, Zielona Góra 2002, s. 31-33.

J. Naczyńska, (w:) Kodeks cywilny. Komentarz, op. cit., s. 238. 
Possessio nuda, czyli czy istnieje jeszcze funkcja prawno-korygująca posiadania...

wydania rzeczy, ale tego nie uczyni1 ${ }^{18}$. Zasiedzenie jest uwarunkowane tylko posiadaniem i upływem czasu ${ }^{19}$.

Posiadanie prowadzące do zasiedzenia musi być samoistne i nieprzerwane ${ }^{20}$. Skutek nabycia następuje z mocy samego prawa. Z upływem ostatniego dnia terminu zasiedzenia samoistny posiadacz nabywa prawo własności rzeczy i równocześnie z tym dniem gaśnie prawo własności dotychczasowego właściciela ${ }^{21}$.

Zasiedzieć można tylko prawo rzeczowe, co do którego przepis przewiduje taką możliwość ${ }^{22}$.

\section{Regulacja prawna nabycia własności nieruchomości rolnej w drodze zasiedzenia}

Zgodnie z art. 172 3 kc. nabyć nieruchomość rolną w rozumieniu ustawy wskazanej w art. $166 \S 3 \mathrm{kc}$. przez zasiedzenie może tylko rolnik indywidualny w rozumieniu tej ustawy, o ile powierzchnia nabywanej nieruchomości wraz z nieruchomościami stanowiącymi jego własność nie przekroczy 300 ha użytków rolnych. Jednocześnie zgodnie z treścią art. 14 u.k.u.r. art. $172 \S 3 \mathrm{kc}$. w nowym brzmieniu nie stosuje się, jeżeli zasiedzenie skończyłoby się przed upływem 3 lat od dnia wejścia w życie ustawy o wstrzymaniu sprzedaży nieruchomości zasobu Własności Rolnej Skarbu Państwa oraz o zmianie niektórych ustaw, a zatem do 30 kwietnia 2019 r.

Regulacja dotycząca zasiedzenia odwołuje się do wprowadzonych do porządku prawnego powołaną już ustawą z dnia 14 kwietnia 2016 r. podstawowych zasad nabywania nieruchomości rolnych, to jest, że nabywcą nieruchomości rolnej może być wyłącznie rolnik indywidualny (art. 2 a ust. 1 u.k.u.r.) oraz że powierzchnia nabywanej nieruchomości, wraz z nieruchomościami, które nabywca już posiada, nie może przekroczyć 300 ha użytków rolnych, a pojęcie nabywania nieruchomości rolnych jest aktualnie bardzo szeroko rozumiane ${ }^{23}$.

Wskazane wyżej przepisy nie stanowią novum w polskim ustawodawstwie. Podobną w swej istocie reglamentację w nabyciu nieruchomości rolnej w drodze zasiedzenia zawierał art. 3 ustawy z dnia 29 czerwca 1963 r. o ograniczeniu podziału

18 Ibidem, s. 238, 255. Zasiedzenie należy do szerszego pojęcia instytucji prawnych określonych nazwą dawności, do których zalicza się również przemilczenie, przedawnienie i prekluzję, a których cechą wspólną są negatywne skutki prawne dla osoby uprawnionej z uwagi na niewykonanie przysługujących jej uprawnień przez czas określony w ustawie.

19 A. Stelmachowski, (w:) System Prawa Prywatnego. Prawo rzeczowe, Tom 3, op. cit., s. 393.

20 S. Rudnicki, (w:) G. Bieniek, S. Rudnicki, Nieruchomości. Problematyka prawna, op. cit., s. 1152.

21 J. Naczyńska, (w:) Kodeks cywilny. Komentarz, op. cit., s. 238 i powołana tam literatura.

22 Przede wszystkim zasiedzieć można: prawo własności, prawo użytkowania wieczystego, niektóre służebności gruntowe (art. 292 kc.), służebność przesyłu (art. 3054 kc. w zw. z art. 292 kc.).

23 K. Czerwińska-Koral, Pojęcie nieruchomości rolnej jako wyznacznik obrotu nieruchomościami rolnymi, „Rejent, 2016, nr 6, s. 54-55. 
gospodarstw rolnych ${ }^{24}$, przenosząc wszystkie szczególne przesłanki nabycia i podziału gospodarstw rolnych, opisane w art. 2, również do nabycia własności gruntów w drodze zasiedzenia ${ }^{25}$. Przy tak ostro wskazanych warunkach nabycia orzecznictwo akceptowało stan dotychczasowego posiadania, wskazując, że nie ma żadnych przeszkód prawnych do utrzymania podziału gospodarstwa rolnego, jaki istniał już na gruncie od lat kilkunastu, chociaż powstałe w wyniku podziału gospodarstwa nie odpowiadają podstawowej normie obszarowej (postanowienie SN z dnia 12 sierpnia 1965 r., III CR 123/65, Legalis).

Kolejno, nieobowiązujący już art. $178 \mathrm{kc} .{ }^{26}$ stanowił, że nie można nabyć przez zasiedzenie części nieruchomości rolnej, jeżeli według przepisów o ograniczeniu podziału gospodarstw rolnych nabycie tej części nie byłoby dopuszczalne. Przepis ten wyłączał możliwość zasiedzenia tylko w sytuacjach sprzecznych z art. 163 kc. i miał zastosowanie do wszelkich nieruchomości rolnych bez względu na to, gdzie były położone ${ }^{27}$. Celem tej regulacji było to, aby nie sankcjonować $\mathrm{w}$ drodze zasiedzenia sprzecznych z postanowieniami art. 163 kc. stanów faktycznych, które strony mogą stwarzać w zamiarze obejścia ograniczenia obrotu ${ }^{28}$. Niemniej jednak judykatura opowiadała się za pewnymi wyjątkami, uznając np. za dopuszczalne nabycie własności w drodze zasiedzenia części działki siedliskowej wchodzącej w skład gospodarstwa przez spadkobiercę, który nie zachował uprawnień do dziedziczenia gospodarstwa rolnego (por. orzeczenie Sądu Najwyższego z dnia 14 maja 1986 r., III CZP 19/86 OSNCP nr 2-3, poz. 87 poz. 34).

\section{Przedmiot i przesłanki nabycia własności nieruchomości rolnej w drodze zasiedzenia}

Pierwszą kwestią jest określenie przedmiotu zasiedzenia w rozumieniu znowelizowanych przepisów. Zgodnie z art. $172 \S 3$ kc. przedmiotem nabycia przez zasie-

24 Dz.U. nr 28, poz. 168; uchylony z dniem 1 stycznia 1965 r. przez Przepisy wprowadzające Kodeks cywilny z dnia 23 kwietnia 1964 r. (Dz.U. nr 16, poz. 94).

25 Zgodnie $z$ art. 2 gospodarstwo rolne może być podzielone w drodze zbycia jego części, działu spadku albo zniesienia współwłasności tylko wtedy, gdy części utworzone przez podział bądź same przez się, bądź też wraz z gruntami stanowiącymi już własność nabywcy odpowiadają podstawowym normom obszarowym; gospodarstwo rolne może być podzielone w drodze zbycia lub zniesienia współwłasności również wtedy, gdy nabywcą części gruntów w drodze zbycia lub zniesienia współwłasności jest właściciel gospodarstwa rolnego odpowiadającego minimalnym normom obszarowym, a nabywana część gruntów ma wejść w skład tego gospodarstwa, przy czym: 1) pozostała część gruntów gospodarstwa, które ma ulec podziałowi, będzie odpowiadała podstawowym normom obszarowym lub 2) obszar gospodarstwa, które ma ulec podziałowi, jest mniejszy od minimalnych norm obszarowych, lub 3) obszar gospodarstwa, które ma ulec podziałowi, jest mniejszy od podstawowej normy obszarowej, ale w wyniku podziału obszar gospodarstwa nabywcy po jego uzupełnieniu będzie większy od obszaru gospodarstwa, które ma ulec podziałowi, bądź też to ostatnie gospodarstwo w wyniku podziału ulegnie likwidacji.

26 Przepis art. 178 kc. został uchylony ustawą z dnia 26 października 1971 r. (Dz.U. nr 27, poz. 252).

27 Ograniczenia wypływające $z$ tego przepisu nie miały zastosowania do nabycia w drodze zasiedzenia gruntów rolnych wniesionych do rolniczej spółdzielni produkcyjnej tytułem wkładu w wypadkach określonych w art. 104 § 3 ustawy o spółdzielniach i ich związkach z dnia 17 lutego 1961 roku (Dz.U. 1961 nr 12, poz. 61).

28 J.St. Piątkowski, (w:) F. Błahuta, J.St. Piątkowski, J. Policzkiewicz, Gospodarstwa rolne. Obrót, dziedziczenie, podział, Warszawa 1967, s. 71. 
Possessio nuda, czyli czy istnieje jeszcze funkcja prawno-korygująca posiadania...

dzenie jest nieruchomość rolna w rozumieniu ustawy wskazanej w art. $166 \S 3 \mathrm{kc}$. Przepis art. $166 \S 3 \mathrm{kc}$. odwołuje się do pojęcia nieruchomości rolnej w rozumieniu przepisów ustawy o kształtowaniu ustroju rolnego. Według art. 2 pkt 1 u.k.u.r. nieruchomość rolna to nieruchomość rolna w rozumieniu kodeksu cywilnego, z wyłączeniem nieruchomości położonych na obszarach przeznaczonych w planach zagospodarowania przestrzennego na cele inne niż rolne. Według art. $46^{1} \mathrm{kc}$. nieruchomościami rolnymi (gruntami rolnymi) są nieruchomości, które są lub mogą być wykorzystywane do prowadzenia działalności wytwórczej w rolnictwie w zakresie produkcji roślinnej i zwierzęcej, nie wyłączając produkcji ogrodniczej, sadowniczej i rybnej. Pod zakres zastosowania normy wynikającej z artykułu $172 \S 3$ kc. podpada zatem każda nieruchomość odpowiadająca charakterystyce z art. 2 pkt 1 u.k.u.r. niezależnie od jej powierzchni. Przy ustaleniu cech nieruchomości rolnych podlegających szczególnej regulacji zasiedzenia obojętne są ograniczenia obszarowe wskazane w definicji gospodarstwa rolnego zawartej w u.k.u.r., a także norma 0,3 ha powierzchni nieruchomości rolnej determinująca zakres zastosowania regulacji u.k.u.r., która służy jedynie wskazaniu zakresu zastosowania norm wynikających z u.k.u.r. ${ }^{29}$ Jak bowiem słusznie wskazał R. Michałowski, przepis art. $172 \S 3$ kc. odwołuje się do regulacji u.k.u.r. w trzech wymienionych enumeratywnie aspektach, tj.: w zakresie pojęcia nieruchomości rolnej, pojęcia rolnika indywidualnego oraz sposobu określenia powierzchni 300 ha użytków rolnych jako górnego pułapu gruntów będących własnością rolnika indywidualnego zasiadającego nieruchomość. Innymi słowy, przepis odwołuje się do definicji nieruchomości rolnej, a nie do całej ustawy i zawartych w niej wyłączeń od szczególnych zasad obrotu ${ }^{30}$.

Uwzględniając fakt, że pojęcie nieruchomości rolnej według art. 2 pkt 1 u.k.u.r. jest węższe niż pojęcie nieruchomości rolnej według art. $46^{1} \mathrm{kc}$., możliwe jest zatem, iż dana nieruchomość będzie nieruchomością jedynie w rozumieniu art. $46^{1} \mathrm{kc}$. i wtedy do nabywania w drodze zasiedzenia nieruchomości art.172 § 3 kc. nie będzie miał zastosowania ${ }^{31}$. Tym samym nabycie takiej nieruchomości w drodze zasiedzenia następuje na zasadach ogólnych ${ }^{32}$.

W literaturze podjęto problem skutków posiadania samoistnego w zakresie zasiedzenia gruntu o charakterze mieszanym, czyli częściowo rolnym i częściowo nierolnym. W przypadku posiadania samoistnego takiej nieruchomości przez rolnika

29 W konsekwencji objęte z perspektywy określania przedmiotu zasiedzenia są wyłączenia spod stosowania ustawy o kształtowaniu ustroju rolnego określone w art. 11 ustawy z dnia 14 kwietnia 2016 r. o wstrzymaniu sprzedaży nieruchomości Zasobu Własności Rolnej Skarbu Państwa oraz o zmianie niektórych ustaw.

30 J. Biernat, Nabywanie nieruchomości rolnych w drodze zasiedzenia. Wybrane zagadnienia konstrukcyjne, „Studia Prawnicze. Rozprawy i materiały" 2018, nr 1, s. 148. Odmiennie: C. Dzierzbicki, Stwierdzenie zasiedzenia nieruchomości rolnej, „Rejent” 2018, nr 4, s. 20, 22 oraz chyba R. Michałowski, Kwestie związane z zasiedzeniem nieruchomości rolnej przez rolnika indywidualnego, „Studia luridica Lublinensia”, 2017, nr 1, s. 116.

31 Zob. szczegółowe rozważania na ten temat: K. Czerwińska-Koral, Zasady obrotu nieruchomościami rolnymi w postępowaniach sądowych po 29.04.2016 r. - wybrane zagadnienia, praktyki sądowe. Część 1, „Przegląd Sądowy" 2018, nr 9, s. 80-85.

32 J. Biernat, Nabywanie nieruchomości rolnych w drodze zasiedzenia, op. cit., s. 148. 
indywidualnego mieszany charakter posiadanego gruntu nie ma znaczenia, ponieważ skutek zasiedzenia będzie dotyczył całości gruntu, zarówno części rolnej, jak i nierolnej. Natomiast sprawa określenia sytuacji posiadacza nielegitymującego się przymiotem rolnika indywidualnego $\mathrm{w}$ takiej sytuacji jest problematyczna. Można uznać, że w razie posiadania przez osobę niespełniającą kryteriów wymaganych od rolnika indywidualnego gruntu o mieszanym charakterze skutek zasiedzenia będzie dotyczył jedynie części nierolnej gruntu ${ }^{33}$.

Drugą kwestią są przesłanki zasiedzenia. Podkreślić należy, że przesłanki zasiedzenia nieruchomości rolnej nie zostały wskazane w art. $172 \S 3 \mathrm{kc} .{ }^{34}$ lecz w art. $172 \S 1$ i 2 kc. i są nimi: posiadanie samoistne oraz upływ odpowiedniego czasu, którego długość jest determinowana dobrą lub złą wiarą posiadacza. Zatem ustawodawca nie zmodyfikował ogólnych przesłanek nabywania nieruchomości rolnych w drodze zasiedzenia, lecz wprowadził dodatkowo wyłączenie podmiotowo-przedmiotowe ${ }^{35}$.

Pierwsze wyłączenie to wymóg istnienia dodatkowej kwalifikacji podmiotowej po stronie nabywcy ${ }^{36}$, bowiem nabyć przez zasiedzenie nieruchomość rolną w rozumieniu u.k.u.r. może tylko rolnik indywidualny w rozumieniu tej ustawy. Rolnikiem indywidualnym jest osoba fizyczna będąca właścicielem, użytkownikiem wieczystym, samoistnym posiadaczem lub dzierżawcą nieruchomości rolnych, których łączna powierzchnia użytków rolnych nie przekracza 300 ha, posiadająca kwalifikacje rolnicze ${ }^{37}$ oraz co najmniej od 5 lat zamieszkała w gminie, na obszarze której położona jest jedna z nieruchomości rolnych wchodzących w skład gospodarstwa rolnego, i prowadząca przez ten okres osobiście to gospodarstwo (art. 6 ust. 2 pkt 2 u.k.u.r.). Jeśli nieruchomość rolna znajduje się w posiadaniu małżonków, to wystarczające jest dla zasiedzenia nieruchomości, że rolnikiem indywidualnym jest jeden $\mathrm{z}$ nich ${ }^{38}$.

Na skutek opisanych wyżej wymogów ustawy o kształtowaniu ustroju rolnego do zasiedzenia nieruchomości rolnej może dojść jedynie wtedy, gdy samoistny posiadacz spełnia warunki do przypisania mu statusu rolnika indywidualnego. W konsekwencji oznacza to, że nieruchomości rolnej nie może zasiedzieć osoba prawna ani jednostka organizacyjna, o której mowa w artykule $33^{1} \mathrm{kc}$. Jest to znamienne,

33 R. Michałowski, Kwestie związane z zasiedzeniem nieruchomości rolnej przez rolnika indywidualnego, op. cit., s. $120-122$.

34 Tak wydaje się sugerować R. Michałowski, Kwestie związane z zasiedzeniem nieruchomości rolnej, op. cit., s. 126.

J. Naczyńska, (w:) Kodeks cywilny. Komentarz, op. cit., s. 245.

J. Biernat, Nabywanie nieruchomości rolnych w drodze zasiedzenia, op. cit., s. 148.

Określone w art. 6 ust. 2 pkt 2 u.k.u.r.

R. Michałowski, Kwestie związane z zasiedzeniem nieruchomości rolnej, op. cit., s. 122-123. 
Possessio nuda, czyli czy istnieje jeszcze funkcja prawno-korygująca posiadania...

bowiem ograniczenia obrotu nieruchomościami rolnymi znane nieobowiązującemu już od wielu lat art. $160 \mathrm{kc}$. nie rozciągały się na zasiedzenie ${ }^{39}$.

Wyłączenie przedmiotowe $\mathrm{w}$ art. $172 \S 3 \mathrm{kc}$. polega na tym, że nabycie przez zasiedzenie nieruchomości rolnej może nastąpić, o ile powierzchnia nabywanej nieruchomości wraz z nieruchomościami stanowiącymi własność rolnika indywidualnego nie przekroczy 300 hektarów użytków rolnych. Jak podkreślił R. Michałowski, niezrozumiała jest intencja prawodawcy określającego taki wymóg. Aby być rolnikiem indywidualnym $w$ rozumieniu u.k.u.r., łączna powierzchnia użytków rolnych, których dana osoba jest właścicielem, dzierżawcą lub użytkownikiem wieczystym, a także pozostających w posiadaniu samoistnym, nie może przekroczyć wskazanego pułapu. Gdyby dana osoba była posiadaczem samoistnym gruntów, które łącznie $\mathrm{z}$ innymi gruntami, których jest ona właścicielem, dzierżawcą, użytkownikiem wieczystym czy posiadaczem samoistnym, przekraczają 300 ha, nie byłaby wówczas rolnikiem indywidualnym i nie doszłoby do zasiedzenia. W razie zasiedzenia gruntu posiadanego przez rolnika indywidualnego następuje zmiana ze stanu faktycznego, którym jest posiadanie, na tytuł prawny, którym jest nowo uzyskane prawo własności. Samo zasiedzenie nie powoduje $\mathrm{w}$ jakikolwiek sposób powiększenia - względem stanu sprzed zasiedzenia - powierzchni zaliczanej do normy obszarowej wskazanej w artykule 6 ust. 1 u.k.u.r. ${ }^{40}$

\section{Funkcja korygująco-prawna i funkcja ochronna posiadania}

W literaturze prawa cywilnego i rolnego oceniono negatywnie zmianę przepisów w zakresie zasiedzenia nieruchomości rolnych. Wskazano, że to rozwiązanie w żaden sposób nie chroni trwałości produkcyjnej gospodarstwa rolnego, gdyż zasiedzenie następuje w odniesieniu do tych nieruchomości, względem których nie są wykonywane przez właściciela uprawnienia władcze, czego przejawem jest m.in. brak rolniczego wykorzystania gruntu (ius possidendi). Ponadto zwrócono uwagę na występującą niewspółmierność pozycji przy stosowaniu instytucji zasiedzenia, jako że rolnik indywidualny może zasiedzieć każdą nieruchomość bez względu na jej charakter (i ewentualne późniejsze jej przeznaczenie), zaś osoba nieposiadająca statusu rolnika indywidualnego może zasiedzieć jedynie te nieruchomości, które nie mają charakteru rolnego. Co więcej, występujące rozróżnienie nie znajduje żadnego przełożenia na zapewnienie właściwego ukształtowania struktury agrarnej w Polsce ${ }^{41}$.

39 A. Bieranowski, Dekompozycja konstrukcji zasiedzenia w nowym reżimie ograniczeń nabycia własności nieruchomości rolnej - zagadnienia węzłowe i uwagi de lege ferenda, „Rejent”, 2016, nr 5, s. 82.

40 R. Michałowski, Kwestie związane z zasiedzeniem nieruchomości rolnej..., op. cit., s. 123.

41 A. Jurcewicz, Wpływ ustawy z dnia 14 kwietnia 2016 r. o wstrzymaniu sprzedaży nieruchomości Zasobu Własności Rolnej Skarbu Państwa na kształtowanie ustroju rolnego - zagadnienia wybrane, „Studia luridica Agraria” t. 15,2017 , s. 229. 
Dalej, zasadnie podkreślono, że regulacja przewidziana w art. $172 \S 3 \mathrm{kc}$. podważa założenia konstrukcyjne instytucji zasiedzenia. Instytucja ta służy bowiem usankcjonowaniu stanów faktycznych, w których podmiot niebędący właścicielem realizuje w sposób długotrwały swoje uprawnienia do rzeczy jako właściciel. Nabycie własności przez podmiot zasiadujący jest przy tym konsekwencją braku aktywności w zakresie realizacji uprawnień właścicielskich przez właściciela rzeczy (nieruchomości). Przy takim postrzeganiu instytucji zasiedzenia trudno uznać za słuszne wyłączenie możliwości zasiedzenia nieruchomości rolnej, gdy właściciel tej nieruchomości w sposób długotrwały nie wykonuje władztwa nad rzeczą. Prowadzi ono do petryfikacji rozwarstwienia sfery faktu i prawa, godząc w bezpieczeństwo obrotu i interes publiczny. Tak głęboka ingerencja w przepisy kodeksowe dotyczące zasiedzenia została nazwana w literaturze dekompozycją konstrukcji zasiedzenia, wskazując, że instytucję zasiedzenia wtłoczono - wbrew jej naturze - w system ograniczeń (kontroli) obrotu nieruchomościami, a wprowadzenie, jak i kształt uregulowania normującego nabywanie nieruchomości rolnych w drodze zasiedzenia budzą poważne zastrzeżenia między innymi na poziomie konstrukcyjnym ${ }^{42}$.

Pojęcia „dekompozycja” użył W. Pańko w odniesieniu do prawa własności, przy czym wskazał on na dwa znaczenia tego określenia, z których jedno odnosi się do „uniwersalności”, a drugie do „pełności” prawa własności. O ile dekompozycja uniwersalności prawa własności ujawniała się - według Autora - w procesie zróżnicowania modelu własności, o tyle drugi typ dekompozycji - co interesujące z perspektywy podjętej problematyki - odnosił się do tej treści ${ }^{43}$. W tak przyjętej perspektywie spójrzmy jeszcze raz na instytucje zasiedzenia oraz posiadania. Oznacza to wgląd na, a więc na istotę i funkcje posiadania. Według dominującego stanowiska posiadanie jest stanem faktycznym ${ }^{44}$. Posiadanie to władanie rzeczą z wolą władania dla siebie o charakterze trwałym ${ }^{45}$. Z posiadaniem ustawa wiąże jednak określone skutki prawne, a jednym $\mathrm{z}$ nich jest zasiedzenie. To właśnie $\mathrm{w}$ instytucji zasiedzenia objawia się funkcja konstrukcyjno-prawna (korygująca-prawna) posiadania. Między innymi w tej funkcji realizuje cel uporządkowania stosunków własnościo$w_{y c h}{ }^{46}$. Tymczasem wprowadzenie nowej regulacji kodeksowej w zakresie zasiedzenia nieruchomości rolnej powoduje wypaczenie tej funkcji posiadania. Dzieje się tak w przypadku, gdy osoba, która posiada nieruchomość rolną i spełnia przesłanki zasiedzenia wskazane w art. $172 \S 1$ i 2 kc., ale nie ma statusu rolnika indywidual-

42 A. Bieranowski, Dekompozycja konstrukcji zasiedzenia..., op. cit., s. 81 i n.

43 W. Pańko, O prawie własności i jego współczesnych funkcjach, Katowice 2016 (Reprint), s. 97-98.

44 J. Ignatowicz, Ochrona posiadania, Warszawa 1963, s. 119-122; A. Kunicki, (w:) System prawa cywilnego, op. cit., s. 841-842; M. Gocłowski, Posiadanie w ujęciu kodeksu cywilnego (Prawo podmiotowe czy stan faktyczny?), „Państwo i Prawo” 2001, nr 2, s. 44-62; M. Krajewski, Charakter prawny przeniesienia posiadania, Studia Prawa Prywatnego 2013, Tom 3-4, s. 84-86. das, M. Fras (red.), Warszawa 2018, s. 812-813.

46 J. Gołaczyński, (w:) System prawa prywatnego. Prawo rzeczowe. Tom 4, E. Gniewek (red.), Warszawa 2007, s. 25,26 . 
Possessio nuda, czyli czy istnieje jeszcze funkcja prawno-korygująca posiadania...

nego. Co więcej, w razie gdyby posiadacz samoistny nie spełniał kryteriów definicyjnych rolnika indywidualnego, a spełniałby przesłankę okresu posiadania potrzebnego dla zasiedzenia, wówczas skutek w postaci zasiedzenia nastapić może dopiero w momencie, w którym posiadacz spełni wszystkie wymogi ustawowe rolnika indywidualnego, przy czym wymogi zawarte w definicji rolnika indywidualnego wystarczy spełniać w momencie nabycia przez zasiedzenie własności a nie przez cały okres zasiedzenia ${ }^{47}$. J.St. Piątowski wskazywał, że posiadanie jest stanem faktycznym, który może nie być zgodny z prawem, ale mimo to - wyjątkiem art. 178 kc. prowadzi do zasiedzenia ${ }^{48}$. W konsekwencji posiadanie nie spełnia swojej funkcji, nie stanowi korektury własności przejawiającej się w dążeniu do dostosowania stanu prawnego do układu stosunków faktycznych.

Czy można zatem jednoznacznie stwierdzić, że posiadanie nie funkcjonuje i tym samym jest puste, jałowe (nuda possessio)? Próbując odpowiedzieć na to pytanie należy zastanowić się nad powodem zmian przepisów w zakresie zasiedzenia. Zapewne ideologicznym uzasadnieniem dla wprowadzenia nowelizacji tych przepisów są okoliczności wskazane przez ustawodawcę w uzasadnieniu do projektu ustawy $^{49}$, gdzie - jak czytamy - celem wprowadzenia wskazanego uregulowania było zapobieżenie obchodzeniu przepisów normujących obrót nieruchomościami rolnymi, realizujący konstytucyjną zasadę oparcia ustroju rolnego na gospodarstwach rodzinnych i zapewnienie, by nieruchomości rolne pozostawały w dyspozycji, w szczególności były własnością osób faktycznie prowadzących gospodarstwa rolne i osób prowadzących działalność wytwórczą w rolnictwie ${ }^{50}$.

Zastanawianie się nad przyczyną nowelizacji przepisów w zakresie zasiedzenia ma jednakże szerszy kontekst. Jest zarazem pytaniem o tendencje ustawodawcy w zakresie uregulowania posiadania. Wydaje się, że aktualnie ustawodawca odszedł od nurtu ,uporządkowania stanu własnościowego przez dostosowanie stanu własności do posiadania”, na rzecz „oderwania się od stanu własności i oparcia się wyłącznie na stanie posiadania". W literaturze wskazywano już na akty prawne, które w przeszłości odnosiły się do tego nurtu ${ }^{51}$. Tendencja odnoszenia się wprost do stanu posiadania i wiązania z nim określonych skutków prawnych jest nadal widoczna w zakresie obciążania podatkami gruntowymi, obowiązkami z zakresu ubezpieczeń społecznych i ubezpieczeń majątkowych ${ }^{52}$. Kierunek ten jest też widoczny w treści definicji gospodarstwa rolnego z art. $55^{3} \mathrm{kc}$., gdzie ustawodawca oderwał się od kryterium własności, do którego wprost odnosiła się definicja zawarta w roz-

47 A. Bieranowski, Dekompozycja konstrukcji zasiedzenia..., op. cit., s. 87-88; R. Michałowski, Kwestie związane z zasiedzeniem nieruchomości rolnej..., op. cit., s. 119.

48 J.St. Piątowski, (w:) F. Błahuta, J.St. Piątowski, J. Policzkiewicz, Gospodarstwa rolne..., op. cit., s. 60.

49 Druk Sejmu RP VIII kadencji nr 293 z dnia 4 marca 2016 r., uzasadnienie, s. 16.

50 Powołuję za J. Biernatem, Nabywanie nieruchomości rolnych w drodze zasiedzenia..., op. cit., s. 148.

51 Zob. A. Stelmachowski, Istota i funkcja posiadania, op. cit., s. 123-124.

52 D. Łobos-Kotowska, Współczesne funkcje posiadania gruntów rolnych, op. cit., s. 290. 
porządzeniu Rady Ministrów z dnia 28 listopada 1964 r. w sprawie przenoszenia własności nieruchomości rolnych, znoszenia własności takich nieruchomości oraz dziedziczenia gospodarstw rolnych ${ }^{53}$. Podobnie $w$ definicji gospodarstwa rodzinnego brak odwołania do prawa własności (art. 5 u.k.u.r.), a definicja rolnika indywidualnego (art. 6 u.k.u.r.) nawiązuje do różnych tytułów prawnych do użytków rolnych, w tym wprost do posiadania samoistnego i zależnego (dzierżawa). Aktualnie uznaje się, że do prowadzenia gospodarstwa rolnego wystarczy faktyczna możliwość korzystania z gruntów rolnych, niezależnie od rodzaju tytułu prawnego do tych gruntów ${ }^{54}$. Przepisy dotyczące umowy kontraktacji odnoszą się do przeniesienia posiadania (art. 625 i $626 \mathrm{kc}$.). Kolejny przykład dają przepisy ustawy z dnia 28 września 1991 r. o lasach ${ }^{55}$, gdzie definicja właściciela lasu także nawiązuje do posiadania samoistnego i zależnego. Wreszcie, wprowadzenie pięcioletniego moratorium na sprzedaż nieruchomości albo ich części wchodzących w skład Zasobu Własności Rolnej Skarbu Państwa ${ }^{56}$ spowodowało przesunięcie akcentu w gospodarowaniu nieruchomościami Zasobu na dzierżawę, a więc posiadanie.

Współcześnie wskazany kierunek ustawodawczy umacnia się, co wiąże się z przepisami dotyczącymi zasad i trybu przyznawania pomocy unijnej. Takie podejście ustawodawcy wynika stąd, że ochrona w tych przepisach jest określana nie przez tytuł do gruntu, lecz przez funkcje spełniane przez ten grunt (produkcyjna, środowiskowa, społeczna) ${ }^{57}$. W orzecznictwie sądów administracyjnych podkreśla się, że dla uzyskania pomocy unijnej konieczne jest faktyczne posiadanie gospodarstwa rolnego, a nie tytułu prawnego własności. Tytułem uprawniającym do uzyskania płatności jest posiadanie gospodarstwa rolnego w rozumieniu art. $336 \mathrm{kc}$. Posiadanie oznacza zatem stan faktyczny, którego istotą jest fizyczne władztwo nad rzeczą z zamiarem władania rzeczą dla siebie. Co więcej, posiadaczem samoistnym lub zależnym może być również osoba niemająca żadnego tytułu prawnego do posiadania. Przymiot posiadacza ma także osoba władająca rzeczą w złej wierze. W odniesieniu do spraw o przyznanie płatności do działek rolnych przesłanka posiadania działki rolnej nie może być więc rozumiana jako ustalenie tytułu prawnego, z którego wynika to posiadanie ${ }^{58}$. Podkreśla się dodatkowo, że postępowania w przedmiocie do-

R. Budzinowski, Pojęcie gospodarstwa rolnego według kodeksu cywilnego (rozważania na tle art. $55^{3}$ kc.), „Ruch Prawniczy, Ekonomiczny i Socjologiczny” 1991, nr 3, s. 61 i 62; tenże, Koncepcja gospodarstwa rolnego w prawie rolnym, Poznań 1992, s. 88; J. Górecki, Gospodarstwo rolne jako przedmiot zastawu, „Rejent” 2003, nr 4, s. 52; orzecznictwo - np. postanowienie SN z dnia 4 października 2000 r., III CKN 1387, Legalis; wyrok WSA w Olsztynie z dnia 5 marca 2009 r., I SA/I 481/08, Legalis.

Tekst jedn. Dz.U. z 2018 r., poz. 2129 ze zm.

Przepis art. 1 ustawy z dnia 16 kwietnia 2016 r. o wstrzymaniu sprzedaży nieruchomości Zasobu Własności Rolnej Skarbu Państwa oraz zmianie niektórych ustaw (Dz.U. z 2016 r., poz. 585).

D. Łobos-Kotowska, Współczesne funkcje posiadania gruntów rolnych..., op. cit., s. 288.

Tak: WSA z siedzibą w Olsztynie w wyroku z dnia 30 lipca 2009 r., I SA/OI 398/09, Legalis, a także np. wyroki NSA: z dnia 17 stycznia 2008 r., II GSK 227/07 oraz z dnia 2 września 2008 r., II GSK 311/08, orzeczenia.nsa. gov.pl. 
Possessio nuda, czyli czy istnieje jeszcze funkcja prawno-korygująca posiadania...

płat do gruntów rolnych nie mogą służyć regulowaniu własności gospodarstw rolnych (wyrok WSA w Poznaniu, III SA/Po/0759).

Konkludując wskazać należy, że pomimo zmiany przepisów w zakresie zasiedzenia nieruchomości rolnych, posiadanie nie jest puste, a jego funkcja prawno-korygująca działa nadal. Jest tak z uwagi na drugi aspekt tej funkcji przejawiającej się w ustawodawstwie, które odwołuje się wprost do posiadania, abstrahując co do zasady od tytułu własności. Nie można stwierdzić, że posiadanie jest stapiane wraz z upływem czasu z własnością ${ }^{60}$, lecz wręcz abstrahuje od ich rozróżnienia. W tym sensie posiadacz jest ustawiany na równi z właścicielem. W konsekwencji właściciel oddziela się od przedmiotu swojej własności, a gospodarstwo prowadzi posiadacz niemający tytułu własności. Ze względu na rozwój ustawodawstwa unijnego i jego wpływ na polskie przepisy, ten aspekt funkcji posiadania będzie się utrwalał, odsuwając prawo własności na drugi plan. Z tym łączy się funkcja ochronna posiadania. Funkcja ta naturalnie „wypływa” z szeregu przepisów kodeksu cywilnego, w których przewidziana jest ochrona posiadacza. Wynika ona jasno z przepisów kodeksu cywilnego dotyczących dochodzenia rozliczeń między właścicielem rzeczy a posiadaczem (art. 224-230 kc.), roszczenia posiadacza o wykup zajętej części gruntu (art. $231 \S 1 \mathrm{kc}$.), roszczenia o ustanowienie służebności drogi koniecznej (art. $146 \mathrm{w}$ zw. z art. $145 \mathrm{kc}$.). Do funkcji ochronnej odnoszą się również poglądy o dziedziczeniu posiadania ${ }^{61}$. Funkcja ta jest szczególnie widoczna przy posiadaniu rolnym, a zwłaszcza w przepisach dotyczących uzyskania pomocy unijnej, dzięki którym posiadacz uzyskał ochronę swojego posiadania. Na koniec warto postulować zwiększenie przepisów uwzględniających funkcję ochronną posiadania, w tym także posiadania zależnego (dzierżawy).

59 Cytuję za: A. Zieliński, Ekonomiczne wsparcie rozwoju rolnictwa ze środków unijnych w orzecznictwie Wojewódzkiego Sądu Administracyjnego w 2007 r., „Przegląd Prawa Rolnego” 2008, nr 7, s. 269.

60 S. Wójcik, Zasiedzenie jako sposób nabycia praw podmiotowych (znaczenie oraz próba oceny niektórych uregulowań), (w:) Rozprawy z prawa cywilnego. Księga pamiątkowa ku czci W. Czachórskiego, J. Błeszyński (red.), Warszawa 1985, s. 153.

61 Np. postanowienie SN z dnia 28 kwietnia 1999 r., I CKU 10/98, OSNC 1999 nr 11, poz. 197; wyrok SN z dnia 24 stycznia 2008 r., I CSK 327/07, Legalis; wyrok SA w Warszawie z dnia 20 grudnia 2011 r., VI ACa 865/11, LEX nr 1237757. 
POSSESSIO NUDA, OR IS THERE STILL A LEGAL-CORRECTING FUNCTION FOR POSSESSION AGRICULTURAL LANDS?

Keywords: possession, possession functions, ownership correction, prescription

Possession in agricultural relations has various functions. The change in the regulations on acquisitive prescription of agricultural real estate provokes questions as to fulfillment by having its functions. In particular, the question arises whether the possession function as a proof of ownership still exists, which is ensured by the institution of prescription. Nowadays, the legislation undermines the role of property law by referring to possession. This means that possession is not empty but it functions, and ownership becomes abstract. Nowadays, the laws create the protective function of agricultural possession.

\section{Bibliografia:}

Bieranowski A., Dekompozycja konstrukcji zasiedzenia w nowym reżimie ograniczeń nabycia własności nieruchomości rolnej - zagadnienia węzłowe i uwagi de lege ferenda, „Rejent” 2016, nr 5.

Biernat J., Nabywanie nieruchomości rolnych w drodze zasiedzenia. Wybrane zagadnienia konstrukcyjne, „Studia Prawnicze. Rozprawy i materiały” 2018, nr 1.

Budzinowski R., Pojęcie gospodarstwa rolnego według kodeksu cywilnego (rozważania na tle art. $55^{3}$ kc.), „Ruch Prawniczy Ekonomiczny i Socjologiczny” 1991, nr 3.

Budzinowski R., Koncepcja gospodarstwa rolnego w prawie rolnym, Poznań 1992.

Czerwińska-Koral K., Pojęcie nieruchomości rolnej jako wyznacznik obrotu nieruchomościami rolnymi, ,Rejent” 2016, nr 6.

Czerwińska-Koral K., Zasady obrotu nieruchomościami rolnymi w postępowaniach sądowych po 29.04.2016 r. - wybrane zagadnienia, praktyki sądowe. Część 1, „Przegląd Sądowy” 2018, nr 9.

Dzierzbicki C., Stwierdzenie zasiedzenia nieruchomości rolnej, „Rejent” 2018, nr 4.

Gniewek E., Prawo rzeczowe, Warszawa 2002.

Gocłowski M., Posiadanie w ujęciu kodeksu cywilnego (Prawo podmiotowe czy stan faktyczny?), „Państwo i Prawo” 2001, nr 2.

Górecki J., Gospodarstwo rolne jako przedmiot zastawu, „Rejent” 2003, nr 4.

Ignatowicz J., Ochrona posiadania, Warszawa 1963.

Janeczko E., Zasiedzenie, Zielona Góra 2002.

Jurcewicz A., Wpływ ustawy z dnia 14 kwietnia 2016 r. o wstrzymaniu sprzedaży nieruchomości Zasobu Własności Rolnej Skarbu Państwa na kształtowanie ustroju rolnego - zagadnienia wybrane, „Studia Iuridica Agraria”, t. 15, 2017.

Kołodziejski S., Ekonomiczna i społeczna funkcja posiadania, „Palestra” 1966, nr 6.

Kołodziejski S., Jurydyczna funkcja posiadania, „Palestra” 1967, nr 5. 
Kozińska J., (w:) Kodeks cywilny. Komentarz, t. II. Własność i inne prawa rzeczowe (art. 126-352), M. Habdas, M. Fras (red.), Warszawa 2018.

Kunicki A., (w:) System prawa cywilnego, praca zbiorowa, Tom II, Wrocław 1985.

Krajewski M., Charakter prawny przeniesienia posiadania, Studia Prawa Prywatnego 2013, t. 3-4.

Łobos-Kotowska D., Współczesne funkcje posiadania gruntów rolnych na gruncie przepisów statuujących pomoc unijną, (w:) Rozprawy z prawa prywatnego. Księga pamiątkowa dedykowana Profesorowi Aleksandrowi Oleszce, (red.) A. Dańko-Roesler, J. Jacyszyn, M. Pazdan, W. Popiołek, Warszawa 2012.

Michałowski R., Kwestie związane z zasiedzeniem nieruchomości rolnej przez rolnika indywidualnego, „Studia Iuridica Lublinensia” 2017, nr 1.

Naczyńska J., (w:) Kodeks cywilny. Komentarz, t. II. Własność i inne prawa rzeczowe (art. 126-352), M. Habdas, M. Fras (red.), Warszawa 2018.

Pańko W., O prawie własności i jego współczesnych funkcjach, Katowice 2016 (Reprint).

Piątkowski J.St., (w:) F. Błahuta, J.St. Piątkowski, J. Policzkiewicz, Gospodarstwa rolne. Obrót, dziedziczenie, podział, Warszawa 1967.

Rudnicki S., (w:) G. Bieniek, S. Rudnicki, Nieruchomości. Problematyka prawna, Warszawa 2009.

Skowrońska-Bocian E., (w:) Kodeks cywilny. t. I. Komentarz do artykułów 1-449"11, K. Pietrzykowski (red.), Warszawa 2008.

Stelmachowski A., Istota i funkcja posiadania, Warszawa 1958.

Stelmachowski A., (w:) System Prawa Prywatnego. Prawo rzeczowe, Tom 3, T. Dybowski (red.), Warszawa 2007.

Wójcik S., Zasiedzenie jako sposób nabycia praw podmiotowych (znaczenie oraz próba oceny niektórych uregulowań), (w:) Rozprawy z prawa cywilnego. Księga pamiątkowa ku czci W. Czachórskiego, J. Błeszyński (red.), Warszawa 1985.

Zieliński A., Ekonomiczne wsparcie rozwoju rolnictwa ze środków unijnych w orzecznictwie Wojewódzkiego Sądu Administracyjnego w 2007 r., „Przegląd Prawa Rolnego” 2008, nr 7. 